\title{
Petrography and Geochemistry of Metasedimentary Rocks from the Taku Schist in Kelantan, North-East Peninsular Malaysia
}

\author{
Muhammad Irman Khalif Ahmad Aminuddin ${ }^{1,2}$, Nugroho Imam Setiawan ${ }^{* 1}$, I Wayan \\ Warmada $^{1}$, Kamar Shah Ariffin ${ }^{2}$, and Kotaro Yonezu ${ }^{3}$ \\ ${ }^{1}$ Department of Geological Engineering, Faculty of Engineering, Universitas Gadjah Mada, Yogyakarta, Indonesia \\ ${ }^{2}$ School of Materials and Mineral Resources Engineering, Universiti Sains Malaysia, Nibong Tebal, Penang 14300, \\ Malaysia \\ ${ }^{3}$ Department of Earth Resources Engineering, Kyushu University, 819-0395, Fukuoka, Japan
}

\begin{abstract}
The Taku Schist, located in north-east Peninsular Malaysia, is characterized by its North-South oriented elongated body. It forms part of the Indosinian orogenic build-up generated by the convergence of the Sibumasu continental block and Sukhothai Arc. Petrographic analyses of the metasedimentary rocks sourced from the Taku Schist revealed that the formation was attributable to greenschist's metamorphism into amphibolite facies, which could be observed near the Triassic and Cretaceous intrusions of the Kemahang Granite. The evolution process of the rocks could be linked with the interactions between a contact and regional metamorphisms. The resulting of XRF and ICP-MS geochemical analyses upon the assessment disclosed that the metasedimentary rocks of Taku Schist were made up of greywacke and shale, grouped into the quartzose sedimentary protolith, and belonged to the Continental Island Arc (CIA). It reflects the Taku Schist's episodic contractions, wherein they would lead to the Sibumasu sedimentary cover along with both an accretionary wedge and the genetically-correlated Bentong-Raub mélange to different greenschist. Otherwise associated with amphibolite facies, the facies' conditions and depths were determined according to their position with the Sukhothai Arc's upper plate.
\end{abstract}

Keywords: Peninsular Malaysia · Taku Schist · South-East Asia · Indosinian orogen.

\section{INTRODUCTION}

The metasedimentary rocks of Taku Schist in the north-east region of Peninsular Malaysia formulate a percentage of the Indosinian orogenic and post-orogenic structures found in Southeast Asia. These rocks' formation resulted from subduction and collision experienced by the Sibumasu continental block and Sukhothai Arc during the Permo-Triassic period (Metcalfe, 2002; Ferrari et al., 2008; Ridd, 2012; Morley, 2012). An assessment of the petrological and geochemical properties of sedimen-

\footnotetext{
${ }^{*}$ Corresponding author: N.I. SETIAWAN, Department of Geological Engineering, Universitas Gadjah Mada. Jl. Grafika 2 Yogyakarta, Indonesia. E-mail: nugroho.setiawan@ugm.ac.id
}

tary rocks will be beneficial in evaluating the crucial determinants of both pre-metamorphic sedimentary and orogenic evolutions, as well as their path. Furthermore, research efforts on protolith analysis will also yield novel insight regarding the compositional differences of a depositional environment, protolith, transport, and the source and sink's geotectonic location. Accordingly, a metamorphosed sediment and its composition represent its history and initial evolution, whereas its mineral composition reveals the subsequent development. Regardless, geochemical research efforts encompassing the significant elements and immobile trace elements, including rare earth elements, are likely to be beneficial as reactive indicators 
of source rocks and tectonic setting. Henceforth, this work aims to differentiate newlyobtained data from protolith studies on Southeast Asia basins, specifically the Taku Schist in North-East Peninsular Malaysia. This study will undoubtedly contribute towards the body of knowledge on the regional geodynamic environment and tectonic setting.

\section{Regional GeOlOGY}

The formation of the Indosinian orogeny in Peninsular Malaysia was dated back to the Devonian-Permian subduction and PaleoTethys Ocean closure due to the Triassic collision between the East Malaya Block and Sibumasu continental unit (Metcalfe, 2000). Figure 1a shown the sequel of the subduction and collision events, which have separated the Peninsular Malaysia into three parallel belts according to their variations of magmatism, stratigraphy, mineralization, structure, and metamorphism (Hutchison, 1975 and Metcalfe, 2013). Furthermore, in-depth geochemical and absolute age-dating works have concluded that the primarily sedimentary Central Belt separates the Permian-Lower Triassic I-type Eastern Belt and Late Triassic S-type Western Belt (Ghani et al., 2013; Ng et al., 2015 and Searle et al., 2012). The intrusion of plutons into a well-documented sedimentary succession depicts the measured shift from shallow to deep marine environments, thereby impacting the regionally metamorphosed rocks to different degrees. Such effect includes the accretionary mélange housing the mafic rocks of the Bentong-Raub suture zone (Ali et al., 2016). Accordingly, the area has been positioned as the suture connecting the Sibumasu and East Malaya Block/Sukhothai Arc (Metcalfe, 2000; Metcalfe, 2013 and Hutchison, 2009). In particular, the Taku Schist of North-East Peninsular Malaysia as depicted in Figure $1 \mathrm{~b}$ is notable due to the varying grades of metamorphic rocks lying close to the Late Cretaceous magmatic intrusions (Searle et al., 2012; Hutchison, 2009; Khoo and Lim, 1983 and Ghani, 2000).

Therefore, this region's metasediments have displayed several properties, including greenschist-amphibolite facies metamorphism, an extensive deformation fabric, and residual metamorphosed mafic or acid intrusive.
Moreover, they experienced intrusions due to no small pluton (Kemahang granite) and remain in the proximity of non-metamorphosed to sub-greenschist facies Permo-Triassic sediments (Ali et al., 2016; Hutchison, 2009 and Khoo and Lim, 1983). Meanwhile, the Taku Schist itself presents a north-south elongated body characterized by $80 \mathrm{~km}$-long and 8 to $22 \mathrm{~km}$-wide dimensions. In general, the nonfossiliferous Taku schist's age could not be accurately determined but is presumed to be of the Permo-Triassic period (Khoo and Lim, 1983).

\section{Methodology}

Taku Schist belongs to north-east Peninsular Malaysia and reveals a vast exposure of metamorphic rocks originated from the sediments and subordinate magmatic rocks that will metamorphose into greenschist-amphibolite facies in the later stages. The approximate sampling locations of metasedimentary rocks are marked in Figure 2 accordingly.

In total, 13 metasedimentary rock samples were collected from the research area. The subsequent thin section sample preparation processes and petrographic analyses were carried out at Economic Geology Laboratory, Department of Earth Resources Engineering, Kyushu University, Fukuoka, Japan. Petrographic thin sections were prepared to identify the textural characteristics and the secondary minerals of rocks through observation using a Nikon Eclipse E600 POL microscope equipped with an AdvanCam-U3II camera.

Geochemistry analyses for 13 samples of metasedimentary rocks from Taku Schist were analyzed using X-ray fluorescence (XRF) and Inductively Coupled Plasma-Mass Spectrometry (ICP-MS) methods. For XRF, before the analysis, one 1 gram of each sample was combusted in an electric furnace at $1000^{\circ} \mathrm{C}$ for 2 hours to determine the LOI value. Pressed powdered samples were prepared by pressing at $20 \mathrm{MPa}$ for about 2 minutes in vinyl chloride rings. A Rigaku RIX 3100 XRF spectrometer was utilized in the analysis to determine the bulk major, minor, and trace elemental compositions of the pressed powdered samples. The research's measurement conditions considered were $30 \mathrm{kV}$, and $70 \mathrm{~mA}$, and the JA-3 andesite 


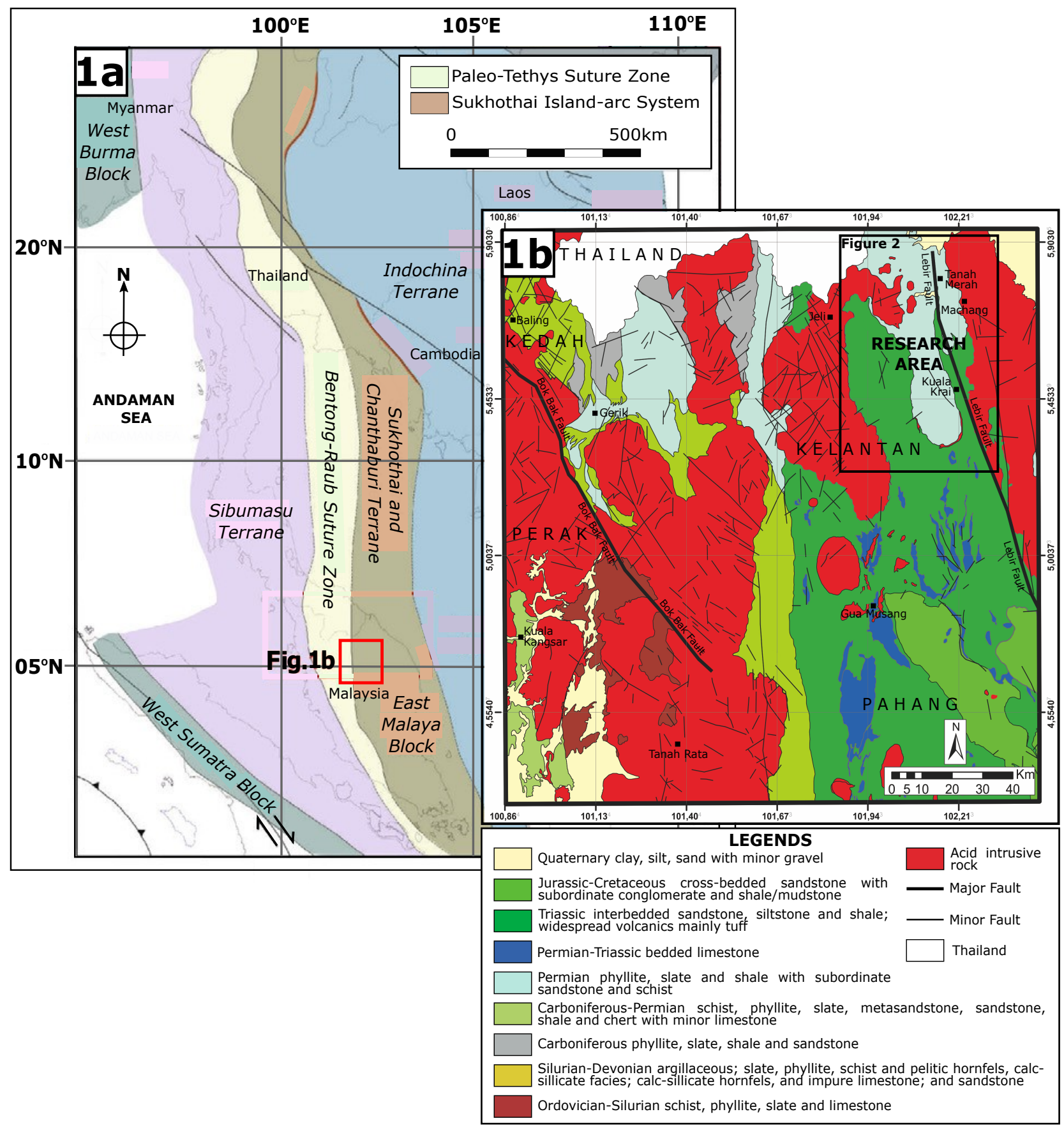

FIGURE 1. (a) Simplified tectonic map of Peninsular Malaysia in terms of Asia continental units and suture zones (modified after Metcalfe, 2013); (b) Simplified geological map of Taku Schist in North-East Peninsular Malaysia. Note the Sibumasu continental unit's demarcation and East Malaya Block via the Bentong-Raub suture zone (modified after Ali et al., 2016). The rectangle in Figure 1a denotes the map's location in Figure $1 \mathrm{~b}$. . 


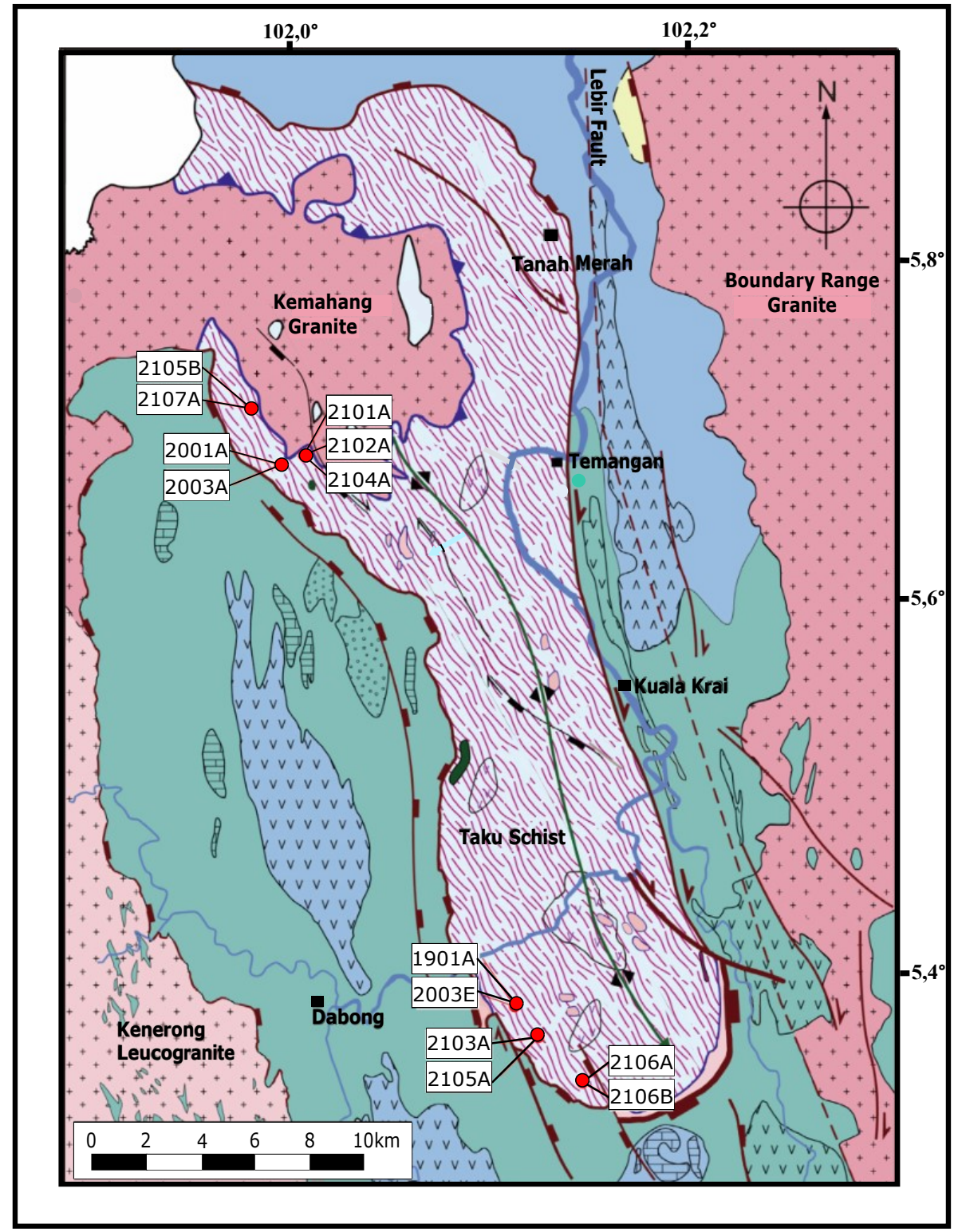

\begin{tabular}{|c|c|}
\hline \multicolumn{2}{|c|}{ LITHOLOGY } \\
\hline & Shale, slate, phyllite \\
\hline 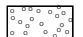 & Sandstone \\
\hline 監需 & Limestone/marble \\
\hline rivist & Schist \\
\hline 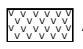 & Acid to intermediate volcanic \\
\hline 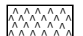 & Intermediate to basic volcanic \\
\hline 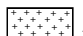 & Acid intrusive \\
\hline & Serpentinite \\
\hline AGE & \\
\hline & Late Cretaceous \\
\hline & Jurassic-Early Creataceous \\
\hline & Middle-Late Triassic \\
\hline & Late Permian-Middle Triassic \\
\hline & Carboniferous-Permian \\
\hline & Silurian-Devonian \\
\hline \multicolumn{2}{|c|}{ LEGEND } \\
\hline \multicolumn{2}{|c|}{ - - Unconformity } \\
\hline \multicolumn{2}{|c|}{$\_$Thrust Fault } \\
\hline \multicolumn{2}{|c|}{ _ Anticline Fold } \\
\hline \multicolumn{2}{|c|}{ Normal Fault } \\
\hline \multicolumn{2}{|c|}{$\longrightarrow$ Strike-slip Fault } \\
\hline 0 & Sampling Point Location \\
\hline \multicolumn{2}{|c|}{ SAMPLE NO \& ROCK TYPE } \\
\hline $2001 \mathrm{~A}$ & Chl-Bt-Ms schist \\
\hline 2107A & Chl-Bt-Ms schist \\
\hline $2105 B$ & Chl-Bt-Ms schist \\
\hline $2103 \mathrm{~A}$ & Chl-Bt-Ms schist \\
\hline 2105A & Chl-Bt-Ms schist \\
\hline $2106 \mathrm{~A}$ & Chl-Bt-Ms schist \\
\hline $2106 B$ & Chl-Bt-Ms schist \\
\hline $2101 \mathrm{~A}$ & Metasandstone \\
\hline $2102 \mathrm{~A}$ & Graphitic Slate \\
\hline 2003E & Mica schist \\
\hline $2003 \mathrm{~A}$ & Ab-Chl-Bt-Ms schist \\
\hline $2104 \mathrm{~A}$ & Ep-Ab-Chl-Bt-Ms schist \\
\hline $1901 \mathrm{~A}$ & St-Chl-Bt-Ms schist \\
\hline
\end{tabular}

FIGURE 2. Detailed geological and structural map of the metasedimentary rock sampling locations for this study (Modified after Ali et al., 2016). The red circles represent the sampling locations plotted on the map with their representative sample codes (white boxes). Abbreviations: $\mathrm{Chl}=$ Chlorite, $\mathrm{Bt}=$ Biotite, $\mathrm{Ms}=$ Muscovite, $\mathrm{St}=$ Staurolite, $\mathrm{Ab}=$ Albite, $\mathrm{Ep}=$ Epidote. 
(Imai et al., 1995) standard was used to monitor the result precision, with an error of less than $5 \%$ was yielded. These XRF analyses were carried out at the Economic Geology Laboratory, Department of Earth Resources Engineering, Kyushu University, Japan.

ICP-MS determined the concentrations of rare earth elements (REE) at the Centre of Advanced Instrument Analysis, Kyushu University, Japan. The ICP-MS sample preparation procedure commenced with the digestion of the sample containing REEs with diluted $\mathrm{HCl}$ solution. The digested sample was added to aluminum sec-butoxide $(\mathrm{Al}(\mathrm{O}-\mathrm{sec}-\mathrm{Bu}) 3$, TBA0) at room temperature before agitation for 2 hours. Subsequently, the solvents of tetraethyl orthosilicate $(\mathrm{Si}(\mathrm{OEt}) 4, \mathrm{TEOS})$ and $\mathrm{N}, \mathrm{N}$-dimethylformamide were added. The sol solution was heated to $160^{\circ} \mathrm{C}$ at a rate of $1^{\circ} \mathrm{C} / \mathrm{h}$ to produce dry gel before further heating to $1000{ }^{\circ} \mathrm{C}$ for 2 hours using a heating rate of 10 ${ }^{\circ} \mathrm{C} / \mathrm{h}$. ICP-MS analyzed the concentrations of REEs after the acid decomposition of the glass.

\section{RESUlts}

\subsection{Field Occurence and Sample Description}

The Chl-Bt-Ms pelitic schist outcrops are the common type of rock identified in the study area. Figure 3a shows one of the Chl-Bt-Ms schist (2001A) samples sourced near the Taku Schist's northern part (Figure 2). Several barren quartz veins have intruded into the ChlBt-Ms schist in this location, which may occur either following the foliation or cross-cutting into the outcrop foliation for contact with the brecciated appearance along with the outcrop (Figure 3b). Generally, the northern part of the Taku Schist is associated with the metamorphism of argillaceous rocks close to the granite margin (Kemahang Granite), thereby resulting in the non-schistose appearance of $\mathrm{Ep}-\mathrm{Ab}-\mathrm{Chl}-$ Bt-Ms schist (2104A) in some localities within the area (Figure 3c). According to MacDonald (1968) in Ali et al. (2016), the Kemahang granite, specifically in this region, is foliated, cataclastically sheared, and made up of numerous schist xenoliths of $107 \pm 3$ Ma age. Bignell and Snelling (1977) reported the K-Ar biotite dating of the Taku Schist as Late Triassic $(212 \pm 8$ $\mathrm{Ma}$ ) with metamorphism near the dome's west- ern margin. Recent U-Pb dating of the Kemahang granite yielded an age estimation of 226.7 $\pm 2.2 \mathrm{Ma}(\mathrm{Ng}$ et al., 2015). As the metamorphism fans outwards away from the granite margins and to the south of the Taku Schist, the subsequent compaction of the rocks and pressure cause plate movements, thus resulting in the formation of low-grade mica schist (2003E) (Figure 3d) and Chl-Bt-Ms schist (2106A) (Figure $3 \mathrm{e}$ ). In particular, the presence of mylonitic and augen textures outcrops (2106B) in this area is a reflection of the complex history behind a brittle-ductile deformation (Figure 3f). As such, the metamorphism of coarse-grained sedimentary rocks such as metasandstone outcrop (2101A) can be found in certain localities (Figure $3 g$ ), whereas a highly folded graphitic slate (2102A) may be identified in some other locations (Figures $3 \mathrm{~h}$ and $3 \mathrm{i}$ ).

\subsection{Petrography}

A summary of results is mentioned in the following passages to delineate the representative samples' petrographic attributes. At the same time, Table 1 lists the estimated modal abundances of minerals for each sample. In general, the sample petrographic analysis indicates that the metasedimentary rocks from the Taku Schist can be grouped into greenschist and amphibolite facies accordingly.

Seven samples of Chl-Bt-Ms schist were analyzed in this study, wherein mica minerals primarily made up of biotite and muscovite were abundantly present in the rock. Meanwhile, other minerals present were predominantly of the quartz and opaque types. In particular, the Chl-Bt-Ms schist sourced from the northern part of the Taku Schist (i.e., 2001A, 2107A, and 2105B) displayed a decussated texture consisting of a muscovite-rich layer made up of randomly oriented interlocking platy, prismatic, or elongated minerals (4a). The texture above was a reflection of the contact metamorphism present in the northern part of the study area, whereby the Triassic Kemahang granite played a role in interconnecting the structures of the Stong Complex and Taku Schist specifically via the intruded dome-shaped structures (MacDonald, 1968 and Francois et al., 2017). Towards the south of the Taku Schist, the same rock type of Chl-Bt-Ms schist (i.e., 2103A, 2105A, 


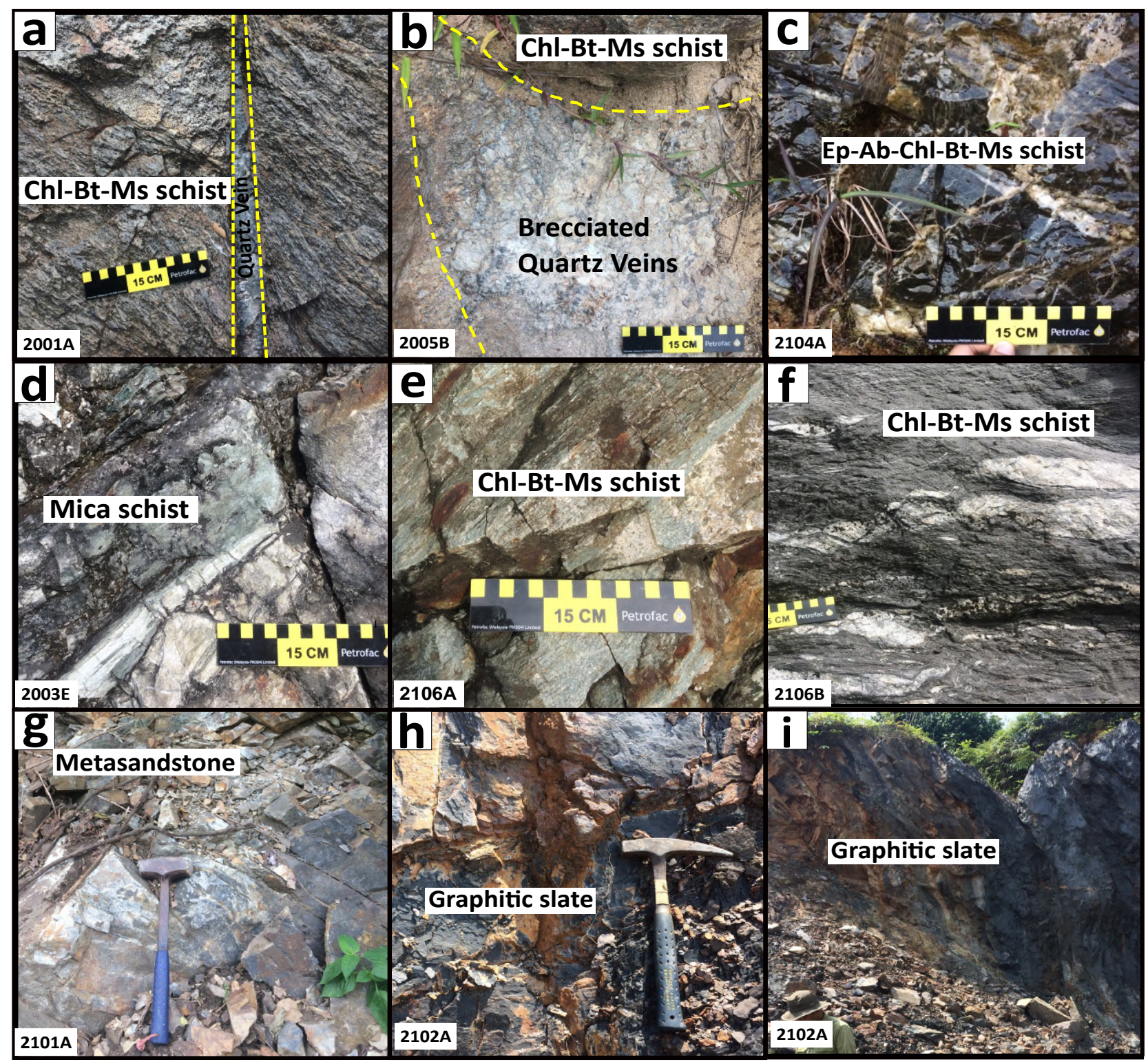

FIGURE 3. Field views of the sampling stations for the metasedimentary rocks sourced from Taku Schist, north-east Peninsular Malaysia. (a) An exposed outcrop of Chl-Bt-Ms schist in the northern part of the Taku Schist. (b) Greenschist facies and brecciated quartz vein contact. (c) The non-schistose appearance of Ep-Ab-Chl-Bt-Ms schist. (d) A boulder of mica schist rock. (e) Greenish Chl-Bt-Ms schist outcrop. (f) An outcrop of highly foliated Chl-Bt-Ms schist in the southern part of the Taku Schist. (g) Exposed metasandstone with several structural joints. (h) A closed dark plate of graphitic slate. (i) Folding of graphitic slate. Abbreviations: $\mathrm{Chl}=$ Chlorite, $\mathrm{Bt}=$ Biotite, $\mathrm{Ms}=$ Muscovite, $\mathrm{Ep}=$ Epidote, $\mathrm{Ab}=$ Albite. 
AMINUDDIN et al.

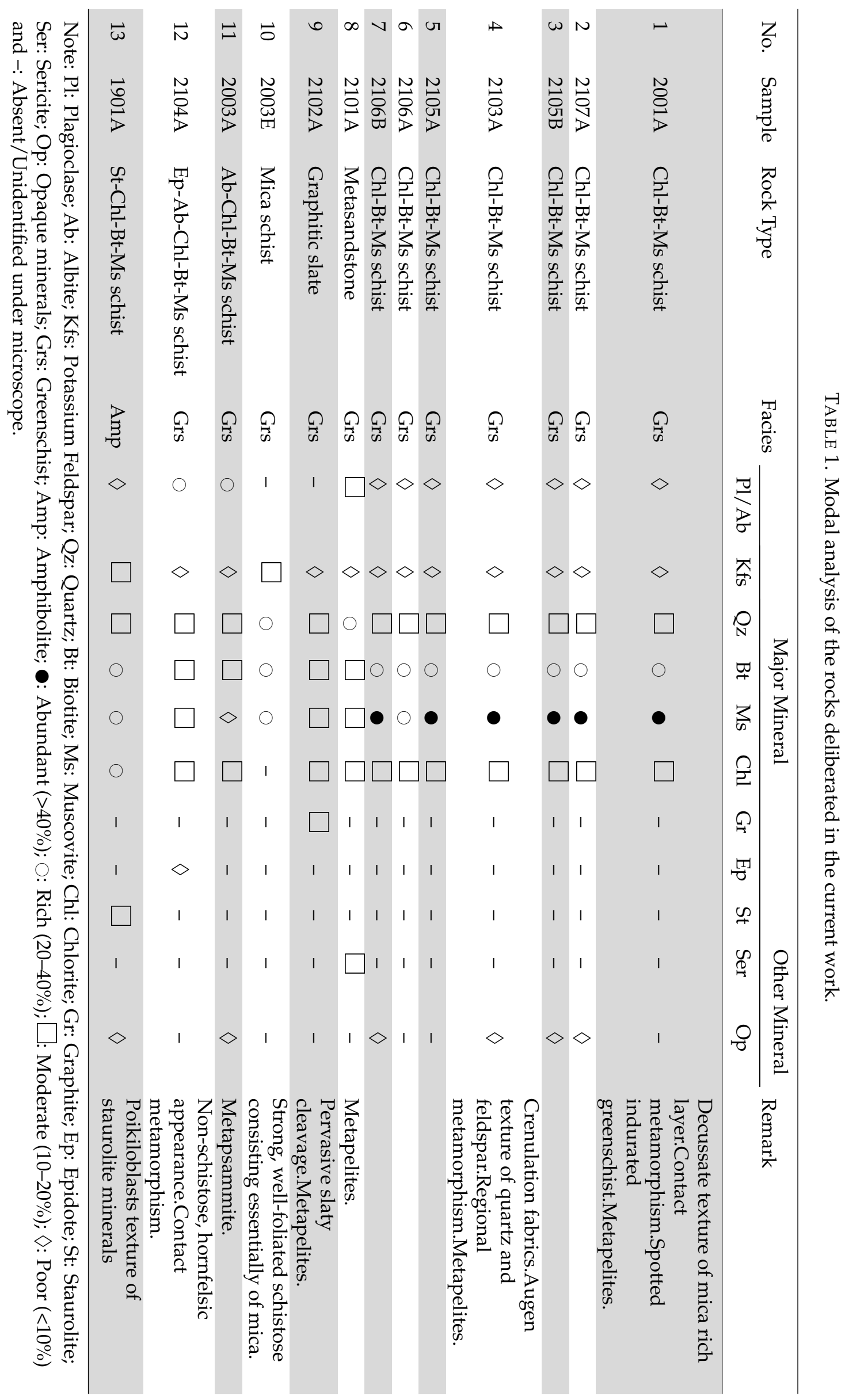


2106A, and 2106B) depicted the crenulation fabrics $(4 b)$ as schistosity. Such crenulation cleavage was generated following the alignment of platy minerals, which were mostly muscovite minerals in nature.

Furthermore, the texture indicated the impact afflicted on the southern part of the Taku Schist due to extensive metamorphic foliation, namely the varying types of planar and linear structures. These include foliations and stretching lineations, folds, faults and striations, and shear zones described by Ali et al. (2016). Almost all Chl-Bt-Ms schist samples consisted of more than $40 \%$ muscovite mineral, followed by biotite (20-30\%), quartz (10$20 \%)$, chlorite $(10 \%)$, plagioclase $(>10 \%)$, and K-feldspar ( $>10 \%)$. Meanwhile, other compositions were of opaque minerals.

In particular, the metasandstone rock sample (i.e., 2101A) yielded minerals such as quartz $(30 \%)$ and feldspar $(10 \%)$, which were typically present in polycrystalline phaneritic clasts displaying a porphyroblastic texture $(4 \mathrm{c})$. Similarly, the lithic grains of metamorphic metapsammite were composed of quartz, muscovite, and sericite fragments (50\%), thereby proving the occurrences of solid-state deformation and recrystallization under the greenschist facies conditions (Palin and Dyck, 2020). In brief, the lowest metamorphism grade was represented by a very fine-grained rock of graphitic slate (2102A), consisting of the detrital grains of quartz $(20 \%)$, minor alkali feldspar $(10 \%)$, and a fine matrix consisting of mica (20\%), graphite $(20 \%)$, and chlorite $(20 \%)(4 d)$. Besides, the intensely deformed shape of rock produced a pervasive slaty cleavage, wherein the original finescale bedding was concurrently disrupted via folding. Additionally, one specific rock sample of mica schist (2003E) yielded good schistosity. The majority of the minerals demonstrated crystalloblastic, nematoblastic, and xenoblastic textures with crystal sizes ranging from $0.5 \mathrm{~mm}$ to $4.0 \mathrm{~mm}$. In particular, its composition was primarily made up of quartz $(30 \%)$, muscovite $(30 \%)$, biotite $(20 \%)$, and K-feldspar $(10 \%)(4 \mathrm{e})$. The Ab-Chl-Bt-Ms rock sample (2003A) predominantly consisted of colorless minerals such as twinned albite $(40 \%)$ and quartz $(20 \%)$ appearing as porphyroclasts. Some of the biotite $(20 \%)$ samples were marked by brown color (4f), while chlorite $(10 \%)$ and muscovite $(5 \%)$ minerals could be observed as a matrix in the samples. The dark- coloration of the specimen for this type of rock indicates a history of intermediate metamorphism with concomitant interbedding between basic volcanic rocks and the original sedimentary rocks.

Moreover, one particular sample of St-ChlBt-Ms schist (i.e., 1901A) contained poikiloblasts of high-relief staurolite $(10 \%)$ and displayed yellow pleochroism $(4 \mathrm{~g})$, thereby frequently consisting of fine-grained quartz and opaque minerals. Meanwhile, the other minerals that concurrently present in the sample included muscovite $(20 \%)$, biotite $(20 \%)$, and quartz $(15 \%)$, with a minor presence of opaque minerals $(>5 \%)$. Besides, one might define this rock's schistosity using mica minerals and opaque grains (4h). The Ep-Ab-Chl schist rock sample (i.e., 2104A), in particular, consisted of epidote $(>10 \%)$, albite $(30 \%)$, biotite $(10 \%)$, muscovite $(10 \%)$, chlorite $(20 \%)$, and quartz $(10 \%)$ (4i). The occurrence of epidote minerals is due to the contamination of felsic igneous rock in this region. Additionally, specific places and those nearby the contact location between Taku Schist and Kemahang granite at the northern part might reveal amphibolite schist. It was suggested that its formation is attributable to metamorphism and direct association with granite intrusion. However, its appearance is not schistose to mica-schist; instead, it is often hornfelsic in nature.

\subsection{Whole-rock Geochemistry}

The compositions of major oxides (wt.\%), trace elements (ppm), and rare earth elements (ppm) in all metasedimentary rock samples from the Taku Schist of north-east Peninsular Malaysia are presented in Table 2. The concentrations of major oxides and trace elements were obtained from the XRF analysis, while the rare earth elements concentrations have resulted from the ICP-MS analysis.

\subsubsection{Major element geochemistry}

Figure 5 displays the distribution of all samples understudy in a $\mathrm{SiO}_{2} / \mathrm{Al}_{2} \mathrm{O}_{3}$ versus $\mathrm{K}_{2} \mathrm{O} / \mathrm{Na}_{2} \mathrm{O}$ diagram according to the grid proposed by Wimmenauer (1984). The grid design was created to clarify clastic sedimentary protoliths, 


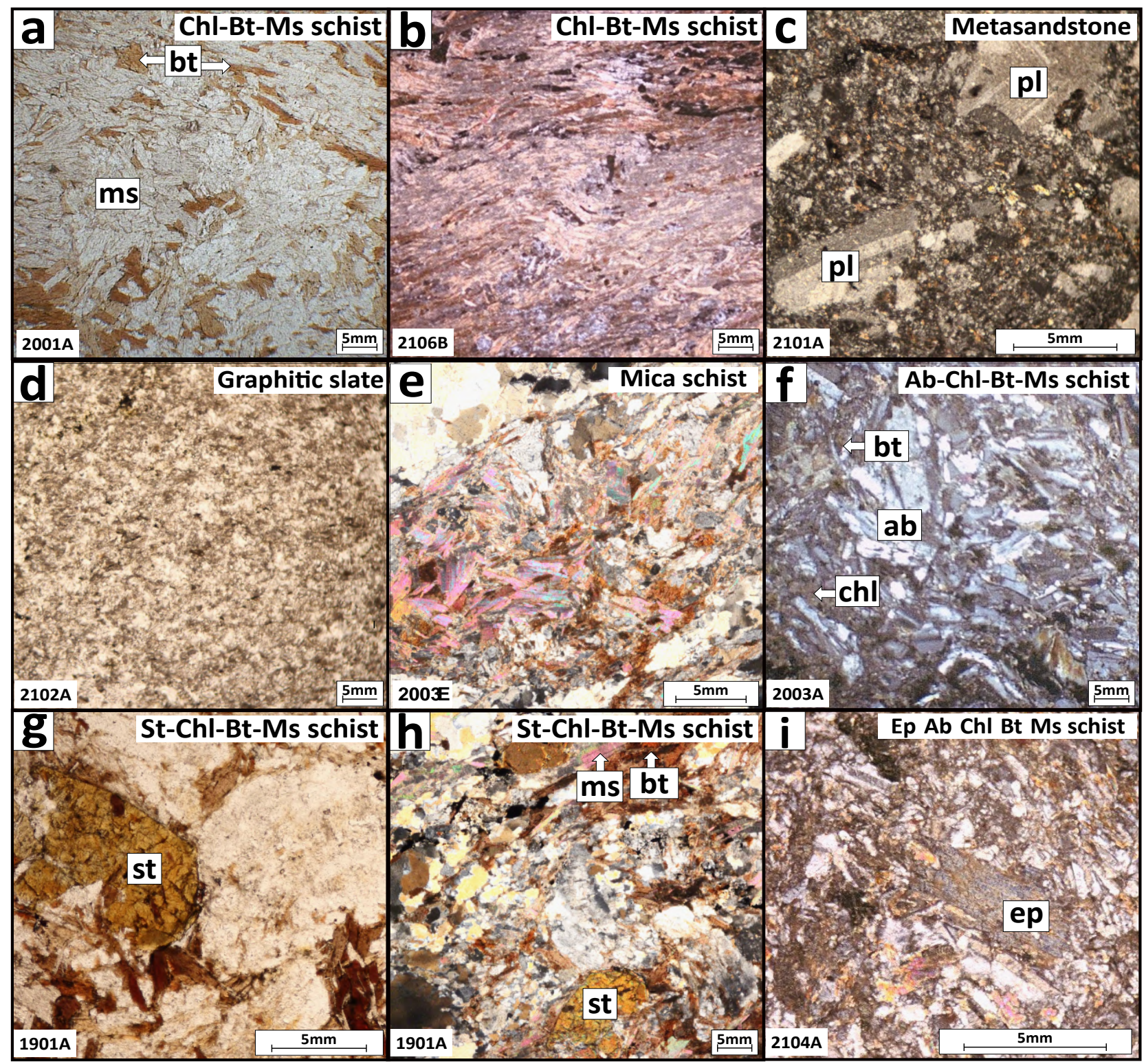

FIGURE 4. Photomicrographs of the rock samples from Taku Schist, north-east Peninsular Malaysia. (a) Decussated texture of Chl-Bt-Ms schist. (b) Crenulation fabric of Chl-Bt-Ms schist. (c) Polycrystalline phaneritic clasts of quartz and plagioclase in the quartz-muscovite-sericite fragments of a metasandstone rock sample. (d) Detrital grains of quartz and minor alkali feldspar with a fine matrix of mica, graphite, and some chlorite of a graphitic slate rock sample. (e) Schistosity of mica schist. (f) Porphyroclasts of twin albite for the Ab-Chl-Bt-Ms schist. (g) A close-up of staurolite mineral. (h) Poikiloblasts of high-relief staurolite in StChl-Bt-Ms schist. (i) Bright and fluorescent color of epidote minerals in Ep-Ab-Bt-Ms schist. Abbreviations: $\mathrm{Chl}=$ Chlorite, $\mathrm{Bt}=$ Biotite, $\mathrm{Ms}=$ Muscovite, $\mathrm{Pl}=$ Plagioclase, $\mathrm{Ab}=$ Albite, $\mathrm{St}=$ Staurolite, $\mathrm{Ep}=$ Epidote . 
TABLE 2. Major (wt.\%) and trace elements (ppm) compositions of representative samples in this study.

\begin{tabular}{|c|c|c|c|c|c|c|c|c|c|c|c|c|c|}
\hline Facies & Grs & Grs & Grs & Grs & Grs & Grs & Grs & Grs & Grs & Grs & Grs & Grs & Amp \\
\hline Sample & 2001A & 2107A & 2105B & $2103 \mathrm{~A}$ & $2105 \mathrm{~A}$ & 2106A & 2106B & $2101 \mathrm{~A}$ & $2102 \mathrm{~A}$ & $2003 E$ & $2003 \mathrm{~A}$ & $2104 \mathrm{~A}$ & $1901 \mathrm{~A}$ \\
\hline 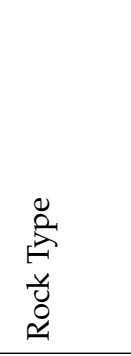 & 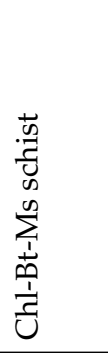 & 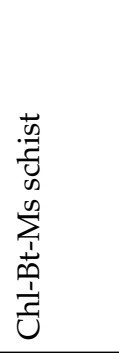 & 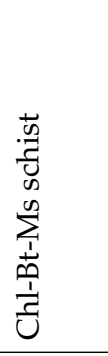 & 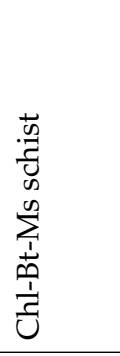 & 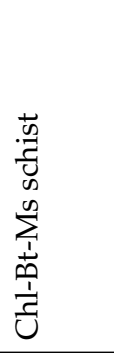 & 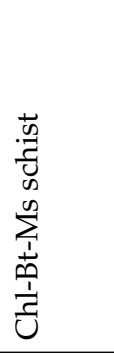 & 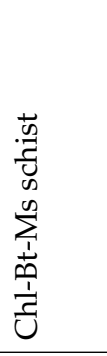 & 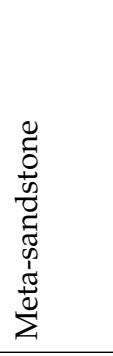 & 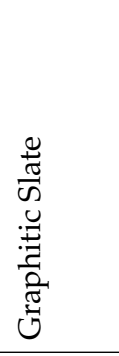 & 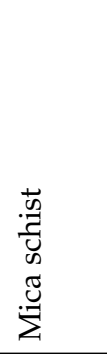 & 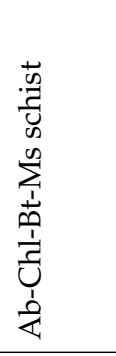 & 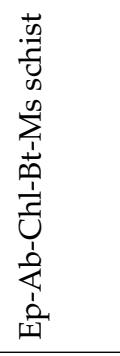 & 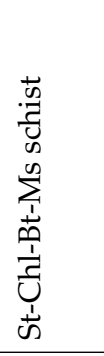 \\
\hline \multicolumn{14}{|c|}{ Major Elements (wt.\%) } \\
\hline $\mathrm{SiO}_{2}$ & 72.47 & 72.38 & 77.15 & 63.86 & 66.31 & 62.17 & 65.11 & 61.7 & 54.28 & 68.44 & 78.83 & 59.31 & 67.33 \\
\hline $\mathrm{TiO}_{2}$ & 0.17 & 0.63 & 0.29 & 0.44 & 0.64 & 0.8 & 0.62 & 0.59 & 0.82 & 0.57 & 0.37 & 0.65 & 0.68 \\
\hline $\mathrm{Al}_{2} \mathrm{O}_{3}$ & 14.09 & 12.82 & 11.29 & 11.05 & 14.99 & 16.37 & 13.3 & 17.59 & 19.67 & 13.57 & 9.06 & 23.49 & 13.59 \\
\hline $\mathrm{FeO}$ & 2.02 & 4.0 & 3.02 & 3.62 & 3.88 & 4.6 & 3.15 & 4.54 & 6.99 & 4.12 & 3.55 & 5.02 & 4.83 \\
\hline $\mathrm{MgO}$ & 1.0 & 2.36 & 1.42 & 1.83 & 2.26 & 2.48 & 2.59 & 1.94 & 3.54 & 2.19 & 1.6 & 0.61 & 2.57 \\
\hline $\mathrm{MnO}$ & 0.02 & 0.07 & 0.06 & 0.18 & 0.09 & 0.1 & 0.12 & 0.19 & 0.04 & 0.08 & 0.04 & 0.01 & 0.19 \\
\hline $\mathrm{CaO}$ & 4.69 & 0.41 & 1.35 & 7.73 & 2.2 & 2.31 & 5.05 & 4.25 & 2.99 & 1.64 & 0.62 & 0.04 & 1.88 \\
\hline $\mathrm{Na}_{2} \mathrm{O}$ & 0.56 & 1.41 & 0.49 & 0.58 & 0.6 & 0.82 & 1.34 & 2.49 & 0.85 & 0.64 & 0.92 & 0.48 & 1.16 \\
\hline $\mathrm{K}_{2} \mathrm{O}$ & 3.0 & 3.46 & 3.13 & 2.54 & 3.8 & 4.06 & 2.45 & 3.73 & 3.97 & 3.13 & 2.09 & 4.09 & 3.13 \\
\hline $\mathrm{P}_{2} \mathrm{O}_{5}$ & 0.07 & 0.12 & 0.11 & 0.13 & 0.18 & 0.17 & 0.12 & 0.07 & 0.13 & 0.17 & 0.22 & 0.01 & 0.15 \\
\hline LOI & 1.7 & 2.18 & 1.21 & 7.58 & 4.67 & 5.68 & 5.63 & 2.64 & 6.51 & 5.16 & 2.11 & 6.14 & 4.08 \\
\hline Total & 99.77 & 99.84 & 99.52 & 99.54 & 99.62 & 99.56 & 99.48 & 99.73 & 99.79 & 99.71 & 99.41 & 99.85 & 99.59 \\
\hline \multicolumn{14}{|c|}{ Trace Elements (ppm) } \\
\hline $\mathrm{V}$ & 28 & 92 & 20 & 132 & 20 & 185 & 92 & 85 & 185 & 114 & 98 & 114 & 182 \\
\hline $\mathrm{Cr}$ & 50 & 46 & 60 & 54 & 64 & 38 & 46 & 70 & 117 & 19 & 38 & 109 & 140 \\
\hline $\mathrm{Ni}$ & 73 & 32 & 13 & 50 & 13 & 24 & 32 & 60 & 96 & 13 & 40 & 13 & 39 \\
\hline $\mathrm{Rb}$ & 52 & 172 & 145 & 24 & 36 & 15 & 172 & 57 & 190 & 177 & 148 & 177 & 456 \\
\hline $\mathrm{Sr}$ & 185 & 47 & 40 & 166 & 40 & 100 & 47 & 161 & 186 & 51 & 68 & 51 & 686 \\
\hline $\mathrm{Zr}$ & 160 & 337 & 260 & 133 & 298 & 340 & 143 & 265 & 211 & 187 & 109 & 342 & 110 \\
\hline $\mathrm{Nb}$ & 3 & 14 & 15 & 7 & 15 & 23 & 14 & 10 & 15 & 14 & 9 & 14 & 12 \\
\hline $\mathrm{Ba}$ & 173 & 679 & 470 & 308 & 288 & 197 & 679 & 908 & 636 & 698 & 438 & 698 & 478 \\
\hline Th & 12 & 4 & 15 & 10 & 6 & 15 & 11 & 7 & 6 & 4 & 12 & 10 & 13 \\
\hline $\mathrm{U}$ & 2 & n.d. & 2 & 1 & 4 & 2 & n.d. & n.d. & n.d. & n.d. & 2 & n.d. & 1 \\
\hline \multicolumn{14}{|c|}{ Rare Earth Elements (ppm) } \\
\hline $\mathrm{Sc}$ & 12. & 4. & 10. & 8.1 & 10.9 & 10.3 & 10.4 & 5. & 6.1 & 9.4 & 10.1 & 8. & 12.4 \\
\hline Y & 8.7 & 9.5 & 13.2 & 12.2 & 7.6 & 7.9 & 4.4 & 9.7 & 3.9 & 4.4 & 5.4 & 8.7 & 4.4 \\
\hline $\mathrm{La}$ & 20.5 & 20.7 & 10.3 & 50.3 & 2.5 & 7.4 & 15.1 & 9.2 & 15.2 & 13.6 & 10.6 & 19.7 & 25.4 \\
\hline $\mathrm{Ce}$ & 24.8 & 38.9 & 21.1 & 22.2 & 27.7 & 29. & 20.6 & 19. & 30.9 & 24.2 & 19.5 & 25.3 & 23.9 \\
\hline $\operatorname{Pr}$ & 5.4 & 4.6 & 2.7 & 2.6 & 3. & 3.4 & 2.4 & 2.4 & 3.7 & 2.8 & 2.3 & 4.9 & 2.8 \\
\hline $\mathrm{Nd}$ & 19.1 & 15.5 & 10.8 & 9.5 & 11.1 & 12.5 & 8.3 & 8.9 & 12.9 & 10. & 8.1 & 16.4 & 9.5 \\
\hline $\mathrm{Sm}$ & 3.7 & 2.9 & 2.6 & 1.9 & 2. & 2.3 & 1.6 & 1.7 & 2.3 & 1.9 & 1.4 & 3.1 & 1.5 \\
\hline $\mathrm{Eu}$ & 0.7 & 0.5 & 0.4 & 0.4 & 0.4 & 0.5 & 0.3 & 0.5 & 0.5 & 0.3 & 0.3 & 0.6 & 0.3 \\
\hline $\mathrm{Gd}$ & 2.9 & 2.7 & 2.5 & 1.8 & 2.2 & 1.9 & 1.3 & 1.9 & 1.8 & 1.6 & 1.4 & 2.7 & 1.5 \\
\hline $\mathrm{Tb}$ & 0.4 & 0.4 & 0.4 & 0.3 & 0.3 & 0.3 & 0.2 & 0.3 & 0.2 & 0.2 & 0.2 & 0.3 & 0.2 \\
\hline Dy & 2. & 2.2 & 2.6 & 2. & 1.7 & 1.7 & 1. & 2.2 & 1.1 & 1. & 1.1 & 2. & 1.1 \\
\hline Ho & 0.3 & 0.4 & 0.5 & 0.4 & 0.3 & 0.3 & 0.1 & 0.4 & 0.2 & 0.2 & 0.2 & 0.4 & 0.7 \\
\hline Er & 1.1 & 1.2 & 1.7 & 1.4 & 0.9 & 1. & 0.6 & 1.4 & 0.6 & 0.6 & 0.5 & 1.3 & 0.5 \\
\hline $\mathrm{Tm}$ & 0.1 & 0.1 & 0.2 & 0.2 & 0.1 & 0.1 & 0.1 & 0.1 & 0.1 & 0.1 & 0.1 & 0.2 & 0.1 \\
\hline $\mathrm{Yb}$ & 0.7 & 1.2 & 1.5 & 1.1 & 0.7 & 0.8 & 0.6 & 1.1 & 0.7 & 0.6 & 0.4 & 1.4 & 0.6 \\
\hline $\mathrm{Lu}$ & 0.1 & 0.2 & 0.2 & 0.2 & 0.1 & 0.1 & 0.1 & 0.2 & 0.1 & 0.1 & 0.1 & 0.2 & 0.1 \\
\hline$\sum$ REE & 102.5 & 105 & 80.7 & 114.6 & 71.5 & 79.5 & 67.1 & 64. & 80.3 & 71. & 61.7 & 95.2 & 85. \\
\hline
\end{tabular}

Note: LOI: Loss on ignition; n.d.: not determined 
wherein the resulting ratios primarily reflect the relative contents of feldspar, quartz, and clay mineral present. It would further help define the samples' schematic variation fields as either graywackes, pelites, arkoses, or others. However, the overall variation of the $\mathrm{SiO}_{2} / \mathrm{Al}_{2} \mathrm{O}_{3}$ (2.5-8.7) and $\mathrm{K}_{2} \mathrm{O} / \mathrm{Na}_{2} \mathrm{O}(1.4-8.5)$ ratios was limited. In particular, most of the samples could be categorized into the graywacke field, while four samples were of the pelitic graywacke field. Meanwhile, only one sample was plotted on the quartz-rich greywacke field.

The $\mathrm{SiO}_{2} / \mathrm{Al}_{2} \mathrm{O}_{3}$ vs. $\mathrm{Fe}_{2} \mathrm{O}_{3} / \mathrm{K}_{2} \mathrm{O}$ diagram (Herron, 1988) in Figure 6 depicts the rocks under the study's protoliths to be wacke derivatives shale, litharenite, and arkose. In particular, the schists with litharenitic protoliths yielded higher concentrations of $\mathrm{SiO}_{2}(>77 \%)$, $\mathrm{Na}_{2} \mathrm{O}$, and $\mathrm{CaO}$. This outcome is in line with the high metamorphic plagioclase content and would possibly depict the detrital plagioclase present in the sedimentary protolith (Lopez et al., 2018). Moreover, the high $\mathrm{SiO}_{2}$ concentrations observed in the samples plotted near the litharenites indicated the significant impact of quartz debris in the sedimentary environment. The schists containing shale and wacke protoliths revealed lower $\mathrm{SiO}_{2}$ concentrations $(<72 \%)$, but high $\mathrm{Al}_{2} \mathrm{O}_{3}, \mathrm{~K}_{2} \mathrm{O}, \mathrm{FeO}$, and $\mathrm{MgO}$ contents were in line the higher mica and chlorite concentrations.

\subsubsection{Rare earth element geochemistry}

The chondrite-normalized rare earth elements (REE) patterns of the rock samples under study are portrayed in Figure 7. Similar chondritenormalized REE patterns were observed for all samples about the Post Archaean Australian Shales (PAAS). However, all samples initially have lower REE contents and exhibit lower than PASS REE normalized values. This could be characterized by LREE enrichment and a slight negative $\mathrm{Eu}$ anomaly in the samples, suggesting the primary sedimentary source was continental crustal rocks in nature (Tang et al., 2012). The $\mathrm{Tm}$ negative anomaly indicates the non-carbonaceous sedimentary rock (JeanAlix, 2016). Three samples (2102A, 2003E, and 2003A) with the lower normalized REE values showed a steeper slope from LREE to HREE (red shaded) compared to other samples.

\section{DisCUSSION}

\subsection{Metamorphism type and metamorphic facies}

Within the research area, various metasedimentary rocks are present, including products of contact and regional metamorphisms. The contact metamorphism is believed to be related to the contact between Kemahang granite and rocks that are hornfelsic in texture. The contact is typically permeated with the development of quartzo-feldspathic minerals (Hutchison, 2009 and Khoo, 1980). The regional type of metamorphism is a part of orogenic metamorphism, which typically produces rock texture with good foliation. The contact and regional metamorphisms can be grouped into high and medium dT/dP metamorphism realms, respectively, according to Palin et al. (2020) on their work of apparent peak metamorphic temperature/pressure $(\mathrm{dT} / \mathrm{dP})$ gradients through time. Therefore, the contact metamorphism (high $\mathrm{dT} / \mathrm{dP}$ ) in this region is related to the island and continental arcs at the convergent plate margins, continental rifts, hot spots, and large margins, deep-seated batholiths. In contrast, the regional metamorphism (medium $\mathrm{dT} / \mathrm{dP}$ ) is related to over thickened continental crust due to accretional or collisional orogeny tectonic regime.

Most of the metasedimentary rocks found within the Taku Schist region were grouped into greenschist facies due to the major presence of chlorite, muscovite, and biotite minerals in the rock samples. According to Winter (2001), this greenschist facies formed at depths of 5-35 km with a pressure condition of $0.1-$ $1 \mathrm{GPa}$ and temperatures of $280-500^{\circ} \mathrm{C}$. Meanwhile, the amphibolite facies are characterized by the presence of staurolite minerals in the rock samples. These amphibolite facies rocks are suggested to form at depths of $8-40 \mathrm{~km}$ with a pressure condition of $0.2-1.2 \mathrm{GPa}$ and temperatures of $500-700^{\circ} \mathrm{C}$ (Winter, 2001).

\subsection{Protolith}

Roser and Korsch's (1988) work has evolved the available discriminant functions to involve major elements in distinguishing the sediments as a derivative of felsic, intermediate, and mafic igneous quartzose sedimentary pro- 


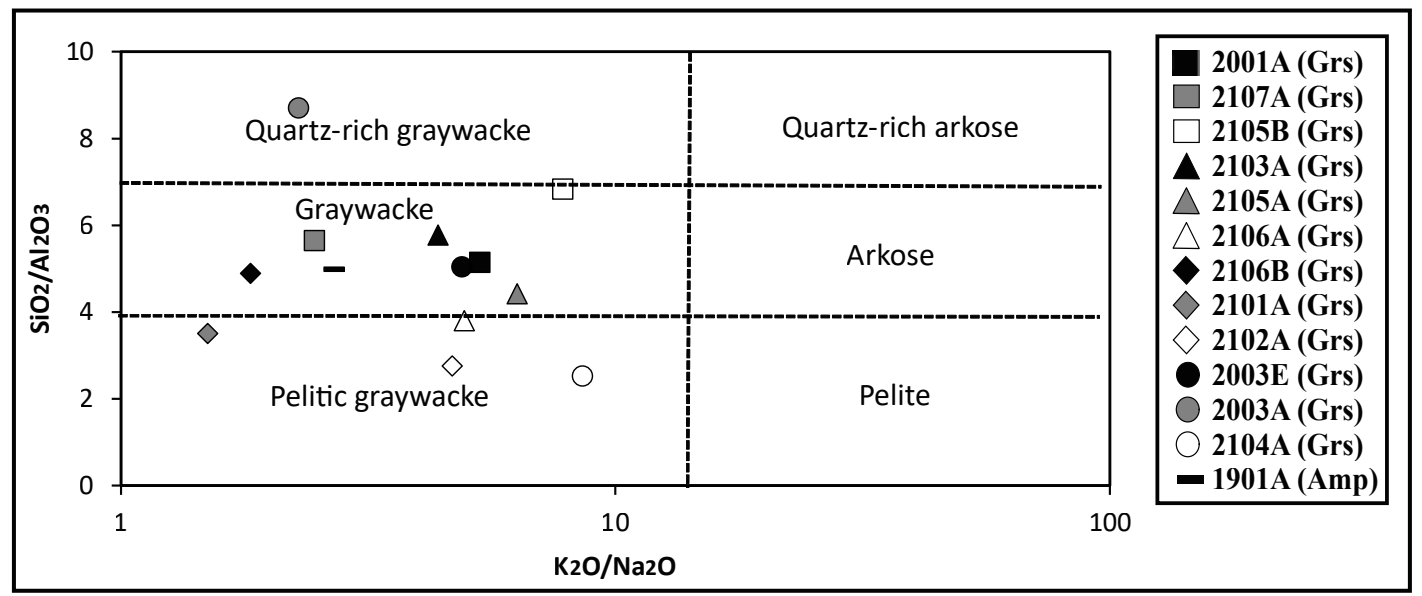

FIGURE 5. Sample distribution on the $\mathrm{SiO}_{2} / \mathrm{Al}_{2} \mathrm{O}_{3}-\mathrm{K}_{2} \mathrm{O} / \mathrm{Na}_{2} \mathrm{O}$ diagram. The subdivision of the composition field into pelitic graywackes, graywacke, quartz-rich graywacke, pelite, arkose, and quartz-rich arkose is after Wimmenauer (1984). Most of the samples belong to the graywackes field, only four samples belong to the pelitic graywackes field, and only one was plotted on quartz-rich graywacke.

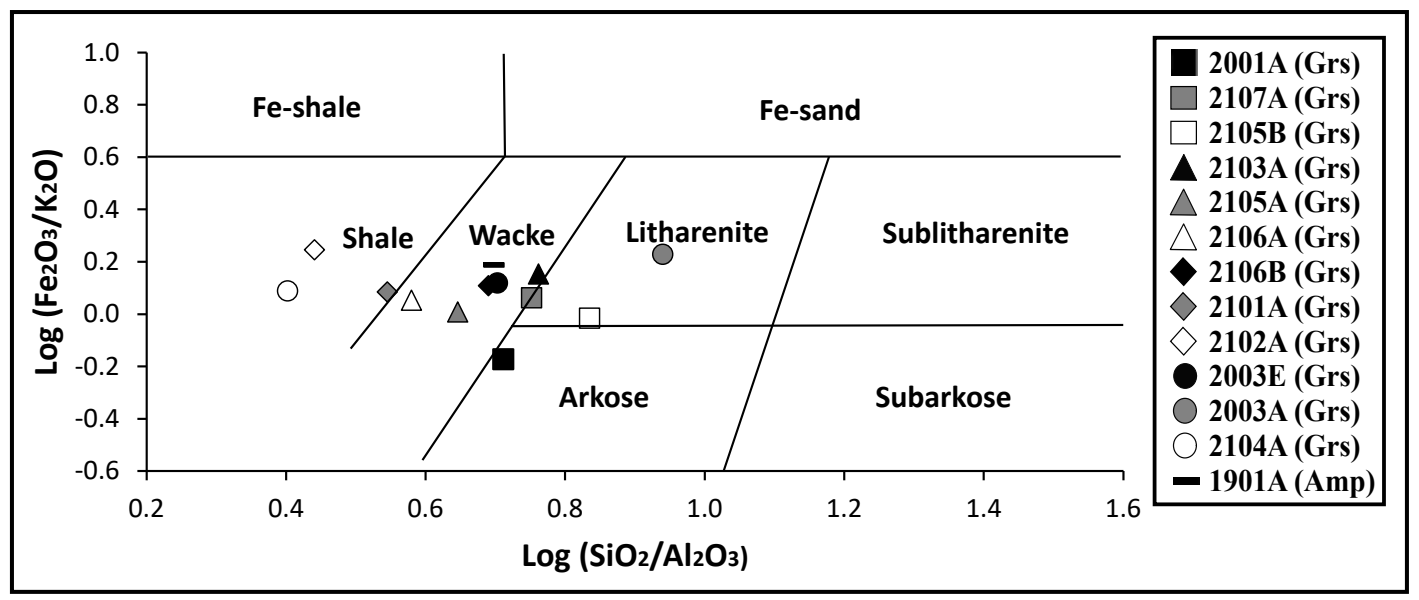

FIGURE 6. Plot of $\log \left(\mathrm{Fe}_{2} \mathrm{O}_{3} / \mathrm{K}_{2} \mathrm{O}\right)$ versus $\log \left(\mathrm{SiO}_{2} / \mathrm{Al}_{2} \mathrm{O}_{3}\right)$ of the analyzed samples within the composition fields proposed by Herron (1988). Almost all of the studied rock samples were plotted on the wacke field. Three samples were plotted on the shale field, while two other samples were plotted on the litharenite field.

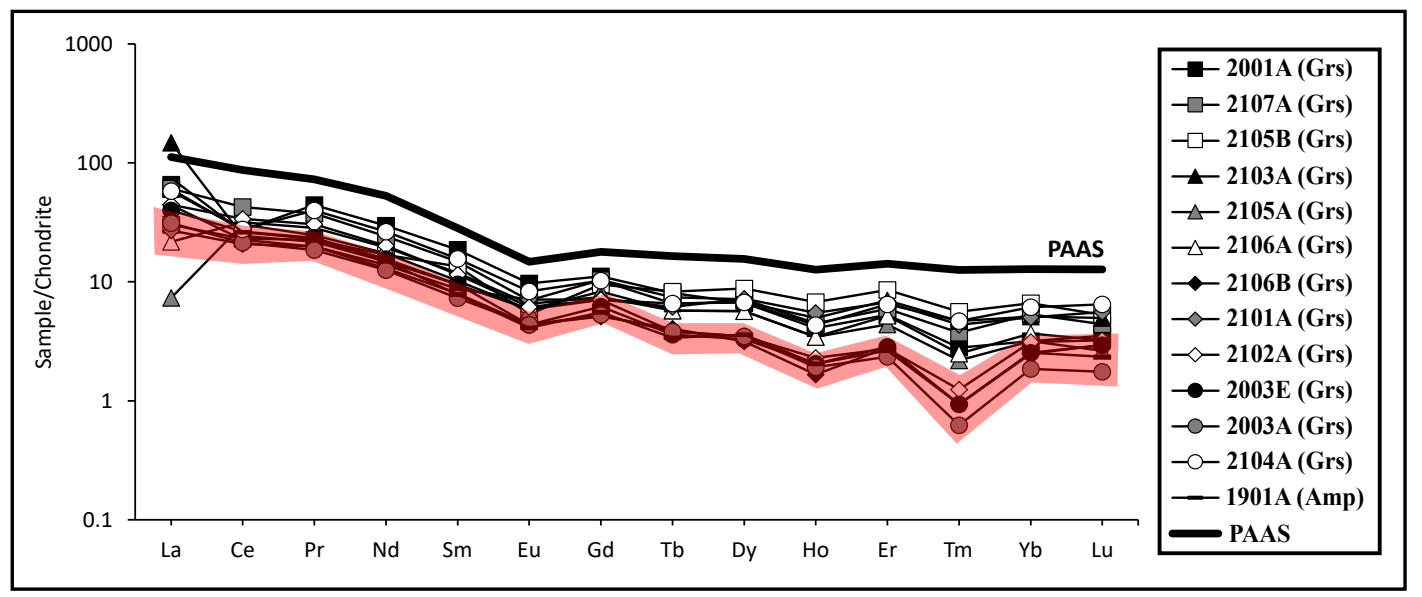

FIGURE 7. Chondrite-normalized REE patterns of the rock samples under study. The normalization factors were referred from MacDonough and Sun (1995). The studied samples demonstrated similar chondritenormalized REE patterns with the Post Archaean Australian Shales (PAAS) provided by (McLennan 1989). 
tolith. Therefore, a plot of the rock samples' chemical compositions under study (Figure 8) revealed them to be predominantly derived from the quartzose sedimentary protolith. This is described in Figure 8a, wherein only four samples could be plotted outside the quartzose sedimentary protolith. Moreover, only one sample (2104A) is plotted in the intermediate igneous protolith as seen in Figure 8a and Figure $8 \mathrm{~b}$ both, which is attributable to the high $\mathrm{Al}_{2} \mathrm{O}_{3}$ and $\mathrm{FeO}$ concentrations and relatively low concentration of $\mathrm{SiO}_{2}$.

\subsection{Tectonic setting}

In general, chemical data is a beneficial instrument in assessing the tectonic setting for ancient sedimentary depositional environments. Accordingly, Bhatia and Crook (1986) have positioned varying discriminant diagrams of tectonic environments concerning sedimentary rocks' geochemical attributes. Henceforth, the $\mathrm{TiO}_{2}$ vs. $\mathrm{Fe}_{2} \mathrm{O}_{3}+\mathrm{MgO}$ ratio (Figure 9a) were considered, wherein most of the samples were plotted onto the Continental Island Arc (CIA) field. In contrast, several others were plotted onto the Active Continental Margin (ACM) field. However, immobile trace elements were known to be highly beneficial in the identification of paleotectonic environments for metasedimentary deposits, such as $\mathrm{Ti}, \mathrm{Sc}, \mathrm{Zr}, \mathrm{La}$, and Th. Therefore, the Ti/Zr vs. La/Sc diagram (Bhatia and Crook, 1986) allowed the visual correlation between the analyzed samples with the CIA and ACM settings (Figure 9b). Moreover, a projection into the diagram of La vs. Th (Figure 9c) reveals that the protolith deposits were comparable to those found in modern continental island arc basins. Additionally, the ternary diagrams of $\mathrm{La}-\mathrm{Th}-\mathrm{Sc}$ and $\mathrm{Th}-\mathrm{Sc}-\mathrm{Zr} / 10$ yielded the samples under study as a group of the CIA field (Figures 10a and 10b).

\section{CONCLUSION}

The petrographic analysis results show the Taku Schist form of sediments and subordinate magmatic rocks were metamorphosed to greenschist-amphibolite facies; in lines with the progression of Indosinian Orogeny, which revealed the Western and Eastern Belts of Peninsular Malaysia represent the lateral extensions of the S-type Sibumasu and Indochina terranes that sutures together as a result of the Indosinian Orogeny. In particular, contact and regional metamorphisms of greenschist to amphibolite facies were near the Triassic and Cretaceous intrusions such as the Kemahang Granite. In the chemical classification efforts, the Taku Schist's metasedimentary rocks were found to consist of greywacke and shale. They could also be grouped into the quartzose sedimentary protolith and the Continental Island Arc (CIA) in the context of their tectonic settings. Additionally, the Taku Schist's metasedimentary rocks would be subjected to several episodes of contraction that would amalgamate the Sibumasu sedimentary cover with the accretionary wedge and genetically correlated Bentong-Raub mélange towards different greenschist to amphibolite facies conditions of varying depths in relation with the upper plate of the Sukhothai Arc.

\section{ACKNOWLEDGEMENTS}

The authors would like to thank the editor and two anonymous reviewers for their constructive comments to improve the manuscript. Our thanks also go to staff members of Geological Engineering Department, Universitas Gadjah Mada (UGM), Indonesia; School of Material and Mineral Resources Engineering, Universiti Sains Malaysia (USM), Malaysia; and Department of Earth Resources Engineering, Kyushu University, Japan, for their supports during this research was carried out. This work is a part of a Ph.D. study supported by JICA AUN/SEEDNet scholarship.

\section{REFERENCES}

Ali, Md.M.A., Willingshofer, E., Matenco, L., Francois, T., Daanen, T.P., Ng, T.F., Taib, N.I., and Shuib, M.K. (2016) Kinematics of post-orogenic extension and exhumation of the Taku Schist, NE Peninsular Malaysia. Journal of Asian Earth Sciences. 127:63-75.

Bhatia, M.R., and Crook, K.A.W. (1986) Trace element characteristics of graywackes and tectonic setting discriminant of sedimentary basins. Contributions to Mineralogy Petrology. 92:181-193.

Bignell, J.D. and Snelling, N.J. (1977) K-Ar ages on some basic igneous rocks from Peninsula Malaysia and Thailand. Bulletin of the Geological Society of Malaysia 8:89-93.

Ferrari, O.M., Hochard, C., and Stampfli, G.M. 

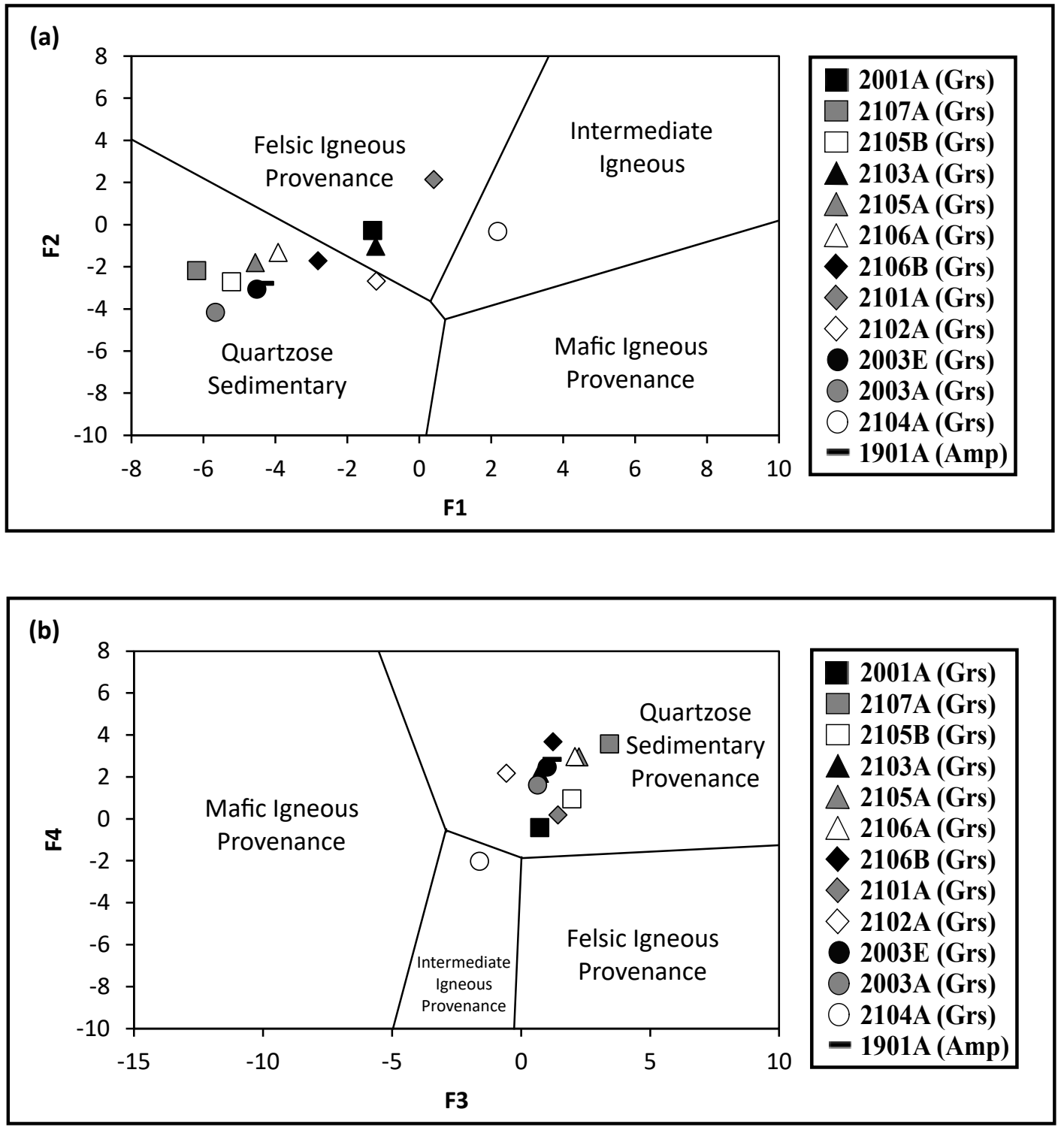

FIGURE 8. Discriminant diagrams of the rock samples (after Roser and Korsch, 1988). The samples were prone to be classified as quartzose sedimentary protolith. However, several samples were plotted on the felsic and intermediate igneous protoliths. $\mathrm{F} 1=-1.773 \times \mathrm{TiO}_{2}+0.607 \times \mathrm{Al}_{2} \mathrm{O}_{3}+0.76 \times \mathrm{Fe}_{2} \mathrm{O}_{3}-1.5 \times \mathrm{MgO}+$ $0.616 \times \mathrm{CaO}+0.509 \times \mathrm{Na}_{2} \mathrm{O}-1.224 \times \mathrm{K}_{2} \mathrm{O}-9.09, \mathrm{~F} 2=0.445 \times \mathrm{TiO}_{2}+0.07 \times \mathrm{Al}_{2} \mathrm{O}_{3}-0.25 \times \mathrm{Fe}_{2} \mathrm{O}_{3}-1.142 \times \mathrm{MgO}$ $+0.438 \times \mathrm{CaO}+1.475 \times \mathrm{Na}_{2} \mathrm{O}+1.426 \times \mathrm{K}_{2} \mathrm{O}-6.861, \mathrm{~F} 3=30.638 \times \mathrm{TiO}_{2} / \mathrm{Al}_{2} \mathrm{O}_{3}-12.541 \times \mathrm{Fe}_{2} \mathrm{O}_{3} / \mathrm{Al}_{2} \mathrm{O}_{3}$ $+7.329 \times \mathrm{MgO} / \mathrm{Al}_{2} \mathrm{O}_{3}+12.031 \times \mathrm{Na}_{2} \mathrm{O} / \mathrm{Al}_{2} \mathrm{O}_{3}+35.4 \times \mathrm{K}_{2} \mathrm{O} / \mathrm{Al}_{2} \mathrm{O}_{3}-6.382$ and $\mathrm{F} 4=56.5 \times \mathrm{TiO}_{2} / \mathrm{Al}_{2} \mathrm{O}_{3}-$ $10.879 \times \mathrm{Fe}_{2} \mathrm{O}_{3} / \mathrm{Al}_{2} \mathrm{O}_{3}+30.875 \times \mathrm{MgO} / \mathrm{Al}_{2} \mathrm{O}_{3}-5.404 \times \mathrm{Na}_{2} \mathrm{O} / \mathrm{Al}_{2} \mathrm{O}_{3}+11.11 \times \mathrm{K}_{2} \mathrm{O} / \mathrm{Al}_{2} \mathrm{O}_{3}-3.89$. 

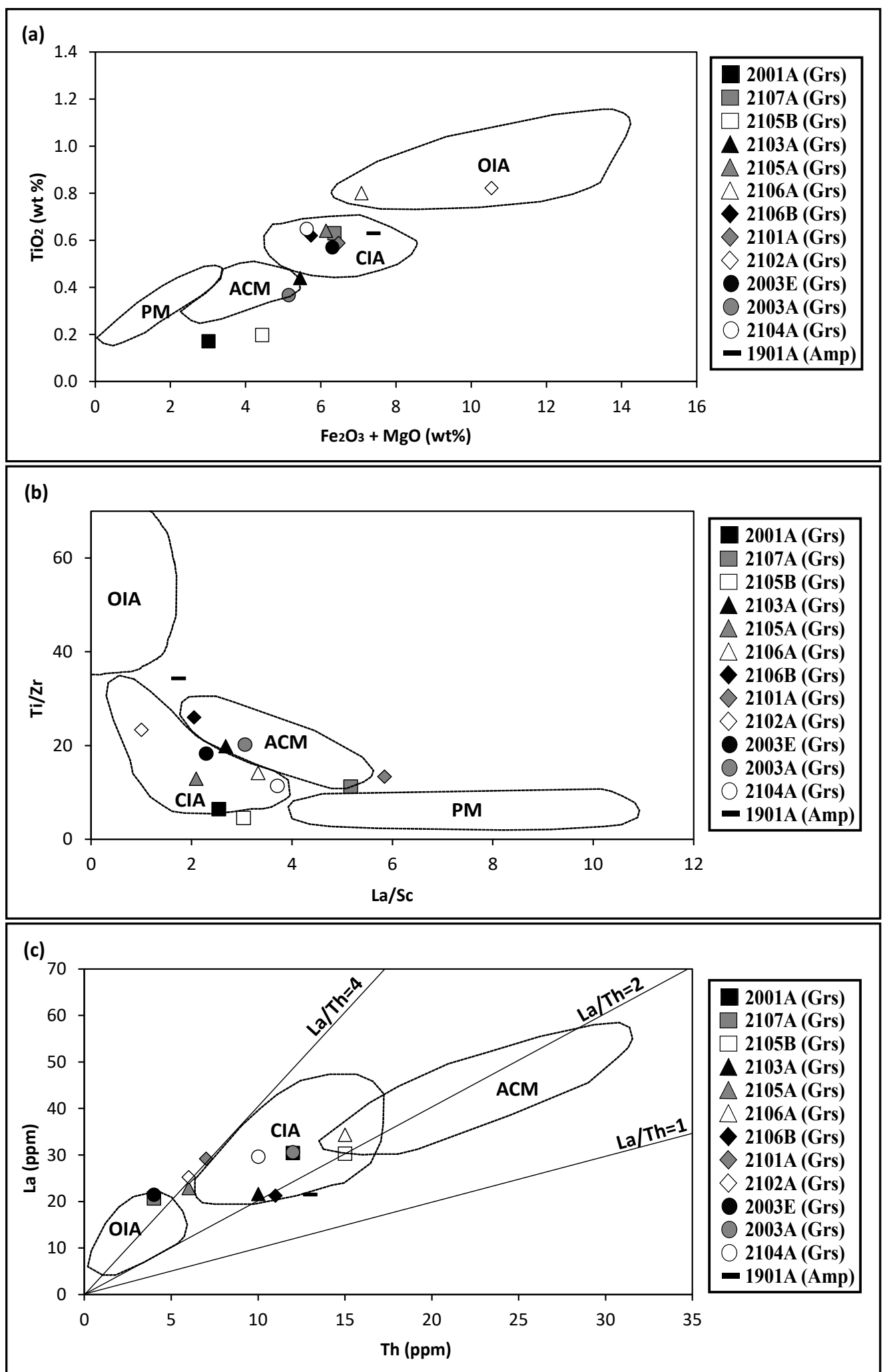

FIGURE 9. Discriminant diagrams depicting potential tectonic setting for the studied rocks. (a) By using the $\mathrm{TiO}_{2}$ (wt.\%) vs. $\mathrm{Fe}_{2} \mathrm{O}_{3}+\mathrm{MgO}$ (wt.\%) diagram (after Bhatia and Crook, 1986), most of the samples could be plotted onto the CIA field with several samples onto the ACM field. (b) Using Ti/Zr vs. La/Sc diagram (after Bhatia and Crook, 1986), the analyzed samples could correlate with the CIA and ACM settings. (c) By using La (ppm) vs. Th (ppm) diagram (after Bhatia and Crook, 1986), the samples mostly belong to the CIA field. ACM: active continental margin, CIA: continental island arc, OIA: oceanic island arc, PM: passive margin. 

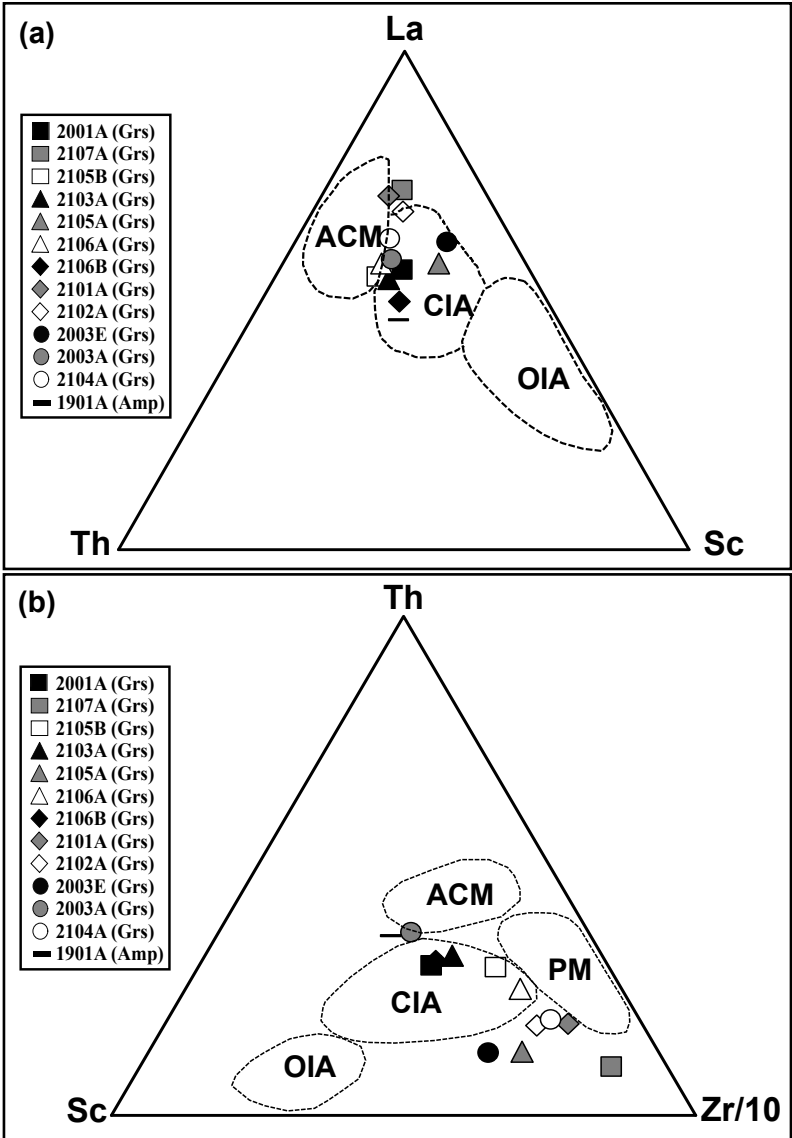

FIGURE 10. Triplots of discriminant diagrams for the tectonic setting of the analyzed rocks. (a) La-Th-Sc diagram (after Bhatia and Crook, 1986). (b) Th-Sc-Zr/10 diagram (after Bhatia and Crook, 1986). Most of the studied samples were plotted on the Continental Island Arc (CIA) field. ACM: active continental margin, CIA: continental island arc, OIA: oceanic island arc, PM: passive margin.

(2008) An alternative plate tectonic model for the Palaeozoic-Early Mesozoic Palaeotethyan evolution of Southeast Asia (Northern ThailandBurma). Tectonophysics. 451:345-365.

Francois, T., Md Ali, M.A., Matenco, L., Willingshofer, E., Ng. T.F., Taib, N.I., and Shuib, M.K. (2017) Late Cretaceous extension and exhumation of the Stong and Taku magmatic and metamorphic complexes, NE Peninsular Malaysia. Journal of Asian Earth Sciences. 143:296-314.

Ghani, A.A. (2000) Mantled feldspar from the Noring granite, Peninsular Malaysia: petrography, chemistry, and petrogenesis. Bulletin of the Geological Society of Malaysia. 44:109-115.

Ghani, A.A., Searle, M., Robb, L., and Chung, S.-L. (2013) Transitional I-S type characteristics in the Main Range Granite, Peninsular Malaysia. Journal of Asian Earth Sciences. 76:225-240.

Herron, M.M. (1988) Geochemical Classification of
Terrigenous Sands and Shales from Core or Log Data. Journal of Sediment Petrology. 58:820-829.

Hutchison, C.S. (1975) Ophiolite in Southeast Asia. Geological Society America Bulletin. 86: 797-806.

Hutchison, C.S. (2009) Metamorphism. In Geology of Peninsular Malaysia, $1^{\text {st }}$ ed.; Hutchison, C. S., Tan, D. N. K, Eds.; The University of Malaya and The Geological Society of Malaysia: Kuala Lumpur, Malaysia.

Imai, N., Terashima, S., Itoh, S., and Ando, A. (1995) 1994 compilation of analytical data for minor and trace elements in seventeen GSJ geochemical reference samples, "Igneous rock series". Geostandards Newsletter. 19:135-213.

Jean-Alix, B., Dauphas, N., Gillet, P., Bollinger, C., Joel, E., Bischoff, A., and Yamaguchi, A. (2016) Evidence from $\mathrm{Tm}$ anomalies for non-Cl refractory lithophile elements proportions in terrestrial planets and achondrites. Geochimica et Cosmochimica Acta. 176:1-17.

Khoo, T.T. (1980) Some comments on the emplacement level of the Kemahang granite, Kelantan. Bulletin of the Geological Society of Malaysia. 13:93-101.

Khoo, T.T. and Lim, S.P. (1983) Nature of the contact between the Taku Schists and adjacent rocks in the Manek Urai area, Kelantan and its implications. Geological Society Malaysia Bulletin. 16:139-158.

Lopez, J.P., Bellos, L.I., Diaz-Alvarado, J., and Castro, A. (2018) Hybridization between I-type and Stype granites in the Ordovician Famatinian magmatic arc, Tafi del Valle, Tucuman, NW Argentina. Geologica Acta. 16:25-43.

MacDonald, S. (1968) The Geology and Mineral Resources of North Kelantan and North Terengganu; Geological Survey West Malaysia: Ipoh, Malaysia.

McDonough, W.F. and Sun, S. (1995) The composition of the Earth. Chemical Geology. 120:223-253.

McLennan, S.M. (1989) Rare earth elements in sedimentary rocks: Influence of provenance and sedimentary processes. Reviews in Mineral. 21:169200.

Metcalfe, I. (2000) The Bentong-Raub Suture Zone. Journal of Asian Earth Sciences. 18:691-712.

Metcalfe, I. (2002) Permian tectonic framework and paleogeography of SE Asia. Journal of Asian Earth Sciences. 20:551-566.

Metcalfe, I. (2013) Tectonic evolution of the Malay Peninsula. Journal of Asian Earth Sciences. 76:195-213.

Morley, C.K. (2012) Late Cretaceous-Early Palaeogene tectonic development of SE Asia. EarthScience Reviews. 115:37-75.

Ng, S.W.P., Whitehouse, M.J., Searle, M.P., Robb, L.J., Ghani, A.A., Chung, S.L., Oliver, G.J.H., 
Sone, M., Gardiner, N.J., and Roselee, M.H. (2015) Petrogenesis of Malaysian granitoids in the Southeast Asian tin belt: Part 2. U-Pb zircon geochronology and tectonic model. Geological Society America Bulletin. 127:1238-1258.

Palin, R.M., and Dyck, B.J. (2020) Metamorphism of Pelitic (Al-rich) Rocks. Encyclopedia of Geology, $2^{\text {nd }}$ Edition: Reference Module in Earth Systems and Environmental Sciences, Elsevier.

Palin, R.M., Santosh, M., Cao, W., Li, S.S., Hernández-Uribe, D., and Parsons, A. (2020) Secular change and the onset of plate tectonics on Earth. Earth-Science Reviews. 207:103-172.

Ridd, M.F. (2012) The role of strike-slip faults in the displacement of the Palaeotethys suture zone in Southeast Thailand. Journal of Asian Earth Sciences. 51:63-84.

Roser, B.P. and Korsch, R.J. (1988) Provenance Signatures of Sandstone-Mudstone Suites Determined Using Discriminant Function Analysis of MajorElement Data. Chemical Geology. 67:119-139.
Searle, M.P., Whitehouse, M.J., Robb, L.J., Ghani, A.A., Hutchison, C.S., Sone, M., Ng, S.W.-P., Roselee, M.H., Chung, S.-L., and Oliver, G.J.H. (2012) Tectonic evolution of the Sibumasu-Indochina terrane collision zone in Thailand and Malaysia: constraints from new U-Pb zircon chronology of SE Asian tin granitoids. Journal of the Geological Society. 169:489-500.

Tang, Y., Sang, L., Yuan, Y., Zhang, Y., and Yang, Y. (2012) Geochemistry of Late Triassic pelitic rocks in the NE part of Songpan-Ganzi Basin, western China: Implications for source weathering, provenance, and tectonic setting. Geoscience Frontiers. 3(5):647-660. Wimmenauer, W., 1984. The pre Variscan crystalline basement of the Black Forest. In German. Fortschr. Mineral. 62:69-86.

Winter, J.D. (2001) An Introduction to Igneous and Metamorphic Petrology; Prentice-Hall Inc.: Upper Saddle River, New Jersey. 